\title{
Cherry-Picking and Demonizing Abilities
}

\begin{abstract}
The disabled people's rights movement coined the term ableism in the 1960's/1970's to highlight problematic uses of ability normativity, and they also coined the term disablism to call out the disabling, the discriminatory use of ableism against disabled people. Ability Studies was coined as a lens, a system analysis tool, to engage with the complex and ever-changing societal reality of ableism and disablism. In my discussion article, I will first give some background on the complexity of the ableism and disablism discussions, then link the concepts of cherry-picking and demonization to the discussions of ableism and disablism. I will suggest that there is a need for much better ability expectation and ableism governance, which is about ascertaining and anticipating disabling impacts of ability expectations and ableism on disabled and non-disabled people and the prevention of such impacts.
\end{abstract}

Keywords: cherry-picking, ableism, ability expectations, walkability, demonizing, disabled people

\section{Rosinenpickerei und die Dämonisierung von Fähigkeiten}

\section{Zusammenfassung}

Die Behindertenrechtsbewegung prägte in den 1960er/1970er Jahren den Begriff des Ableismus, um auf die problematische Verwendung der Fähigkeitsnormativität hinzuweisen. Sie prägte zudem den Begriff des Disablismus (Behindertenfeindlichkeit), um die diskriminierende Verwendung des Ableismus gegenüber behinderten Menschen zu benennen. Ability Studies wurden als eine Linse, ein Systemanalysewerkzeug, geprägt, um sich mit der komplexen und sich ständig verändernden gesellschaftlichen Realität von Abelism und Disablism auseinanderzusetzen. In meinem Diskussionsbeitrag werde ich zunächst einige Hintergrundinformationen zur Komplexität der Diskussionen über Ableismus und Disablismus geben und dann die Konzepte der Rosinenpickerei und Dämonisierung mit den Diskussionen über Ableismus und Disablismus verbinden. Ich werde vorschlagen, dass es einen Bedarf für eine viel bessere Steuerung von Fähigkeitserwartungen und Behindertenfeindlichkeit gibt, bei dem es darum geht, die behindernden Auswirkungen von Fähigkeitserwartungen und Behindertenfeindlichkeit auf behinderte und nichtbehinderte Menschen zu ermitteln und zu antizipieren und solche Auswirkungen zu verhindern.

Schlüsselwörter: Ableismus, Fähigkeitserwartungen, Begehbarkeit, Dämonisierung, Rosinenpickerei, Menschen mit Behinderungen 


\section{Introduction}

The concept of ableism was developed by the disabled people's rights movement during the 1960s and 1970s (Britannica, 2013) to question irrelevant body and mind related ability norms and the "ability privileges (i.e. ability to work, to gain education, to be part of society, to have a positive identity, to be seen as a citizen)" (Wolbring, 2014, p. 119) that come with them. They also coined the term disablism (Miller et al., 2004) to highlight the disabling use of ableism whereby disablism can be active and with that intentional or passive or unintentional, or unconsciously due to for example ignorance or lack of foresight (Wolbring, 2020a).

Ableism and disablism have been applied to many topics and have been theorized extensively such as applying critical race theory (Campbell, 2008), colonial theory (Wolbring \& Ghai, 2015), social dominance theory and social learning theory (Kattari, 2015) or ethics theories (Wolbring, 2012). It is noted that setting something as an ability norm (ableism) is the endpoint of a journey that starts with having ability expectations without these being the set norm yet (Wolbring, 2008a, 2008b) and that ability expectations and ableism are not only used to disable but also to enable (enablism) (Wolbring \& Yumakulov, 2015).

Various ability-based concepts have been generated such as internalized ableism (Campbell, 2008), ability security (one is able to live a decent life with whatever set of abilities one has), ability identity security (to be able to be at ease with ones abilities) and ability inequity, an unjust or unfair (a) "distribution of access to and protection from abilities generated through human interventions" or (b) "judgment of abilities intrinsic to biological structures such as the human body" (Wolbring, 2010, p. 99; 2020a). The intersectionality of ableism and disablism with other forms of oppression such as racism, sexism, ageism and classism is noted (Balderston, 2013; Frederick \& Shifrer, 2019; Liasidou, 2013; Whitesel, 2017).

However, ableism is not only one ism in a list of isms. Setting certain abilities as a norm is often used as a tool by powerful groups and individuals to disable others and it is also used to justify negative isms such as racism, sexism, anti-environmentalism and ageism (Wolbring, 2008a, 2008b). For example, the ability of rationality has been and is still used by powerful groups to enable themselves and disabling other groups by labelling the others as irrational (Wolbring, 2019) (see also discourses around sanism and rationality in mad studies; Eromosele, 2020; Leblanc \& Kinsella, 2016; Morrow, 2017). Men used the rationality argument to support many sexist policies such as the denial of voting rights for women to enable themselves and the ability of cognition is still used to justify racism (Wolbring, 2008a, 2008b). As such, ableism and disablism are a cultural reality going far beyond disabled people (Wolbring, 2020b) impacting humans-human relationships in general, humans-animal and humans-nature relationships (Nocella et al., 2017, 2012; Eco-ability facebook group members, 2016; Roberts-Cady, 2017; Wolbring, 2008a, 2014). Emerging relationships impacted are the relationship between humans- post/transhumans, humans-cyborg humans (Goodley et al., 2014; Wolbring, 2008a, 2008b, 2014) and humans-machines (Wolbring, 2008a, 2008b, 2014). Finally, humanssentient machines (machines that have the ability to be self-aware) is a relationship that might appear in the future. Ableism does not just encompass body/mind linked abilities but also the ability of everyone to live out certain values, beliefs and desires and to have a good life (Wolbring, 2019).

The capability approach developed by Amartya Sen, Martha Nussbaum and Sudhir Anand for evaluating the effects of social change policies on human wellbeing (Human Development and Capability Association, 2021; Robeyns, 2003) reflects that notion (Wolbring \& Burke, 2013). Capability is about what people are able to do and to be (Nussbaum, 2011) and lists of essential capabilities - with other words essential abilities-to-do-andto-be - have been generated within the capability discussions to enable a good life (Alkire \& Black, 1997; Landorf et al., 2008; Nussbaum, 2011; Robeyns, 2003). In other words, the capability approach has as one focus: to enable ability security. In the next three sections I will first introduce the concepts of cherry-picking and demonization and then use 'walkability' as an example of cherry-picking an ability and 'crawling' as an example of demonizing an ability. 


\section{Cherry-Picking and Demonizing Abilities}

Cherry-picking is that one chooses from various valid options to suit oneself and that one ignores the bigger picture or what does not suit oneself. Cherry-picking is discussed in relation to, for example, consumer behaviour (Fox \& Hoch, 2005), policy shopping (Winstanley, 2012), policy evaluation (Walker, 2000), concepts and ideas (Hamilton \& Neimanis, 2018) and scientific evidence (Mizrahi, 2015; Murphy \& Aguinis, 2019). Cherry-picking is seen as a form of or as deriving from confirmation bias (Farmer \& Cook, 2013; Mizrahi, 2015). It can be intentional and unintentional (Vydra \& Klievink, 2019). Demonizing 'the other' is a cultural reality experienced by many (Chesney-Lind \& Eliason, 2006; Jones, 2020; Sripokangkul et al., 2020) including disabled people (Runswick-Cole \& Goodley, 2015; Ryan, 2020). Cherry-picking and demonizing abilities are two actions that influence the journey from ability expectation to ableism and how a given ability expectation and ability norm is used. Many ability-based examples of cherry-picking and demonization exist; I will give one example for each in the next two sections.

\subsection{Cherry-Picking Abilities: The Case of Walkability}

Walkability, a concept employed in academic and non-academic discourses, is the quality of walking such as "safety, comfort, and convenience" (Litman, 2007, p. 1) and having meaningful places to walk to (Avenue Calgary, 2018). Quantifying the value of walking and walkability (Duncan et al., 2011; Frank et al., 2010) focuses on the ability to reach desired places (Seskus, 2011) by foot (walking on two legs with full vision and hearing abilities) (Walk Score, 2018). The measure cherry-picks the ability to walk on two feet with full vision and hearing from various non-motorized modes of mobility. The walkability measures exhibit a passive form of disablism against, for example, wheelchair users and blind and deaf walkers because it only considers making it to a target by using a very specific way of mobility. It also assumes one can make use of all essential parts in a target such as washrooms, which is often not the case (Abraham, 2017). Visitability is a discourse that for example questions the inaccessibility of private homes due to leg-centric designs (internal designs and steps to get to the front door) (Visitability, 2018) but is ignored in the walkability discourse. The walkability discourse exacerbates many ability-based urban design problems identified in relation to disabled people (Edwards, 2021; Hamraie, 2021; Jaffe, 2021). The walkability discourse exhibits at least some form/aspects of ability privileges (accessing targets and ability to move around based on the ability to walk on two legs with full vision and hearing), ability inequity (unjust or unfair distribution of access) and a lack of ability identity security (one will feel less secure in one's ability-based identity if one does not walk on two legs). As is, the walkability concept could lead to a lack of ability security (the ability to have a decent life with one's set of abilities).

\subsection{Demonizing Abilities: The Case of Crawling}

Demonizing an ability as "not normal" is another general societal dynamic: The ability to crawl is such an ability with a recognized negative sentiment (except for toddlers), and this recognized negative sentiment is instrumentalized by many, including by some disabled people, to better the situation of some disabled people (Abraham, 2017; Baafi, 2014; Cerebral Palsy Research Network, 2015; The Asahi Shimbun, 2017; Underwood, 2007; Viney, 2016). Few question the demonization of crawling such as "disabled food vendors that crawl cannot compete with non-crawling vendors due to being perceived as dirty" (Lwanga-Ntale, 2003). That might be due to the fact that many non-walking people might exhibit internalised ableism by adhering to the same negative connotation of crawling that walking people do despite that there are also non-walking people that do not see crawling as "dehumanizing, but for themselves a natural way of moving" (Vehmas, 2004, p. 212). 


\section{Conclusion}

Society and its members constantly change their ability expectations. New ability expectations appear and existing ones become obsolete. A hunter-gatherer society for example expects different abilities than a postknowledge society. The very term "learning disability" appeared in North America (with a neurological defect connotation) in the 1960's after ability expectations of students were changed for high schools (Sleeter, 1986, 1987; Wolbring \& Yumakulov, 2015). Environmental activism, advancements in artificial intelligence, machine learning, automatization and robotics and Covid-19 are some examples of contemporary discussions that influence - currently and in the foreseeable future - the generation of ability expectations and ability norms. All of these examples exhibit at present at least passive if not active disablism in relation to disabled people by not taking into account the potential negative consequences for disabled people (Abrams \& Abbott, 2021; Eskyte et al., 2020; Fenney, 2017; Fenney Salkeld, 2019; Jenks \& Obringer, 2020; Lillywhite \& Wolbring, 2020; Wolbring, 2016; Wong, 2019).

Cherry-picking and demonization influence the perceptions of abilities. Cherry-picking is impactful on the level of where a given ability is not yet the norm as it can elevate this ability by making it visible and making other options invisible, thus enabling this ability to become the norm. Walkability is such an example. Demonizing abilities achieves the same goal by demonizing the not wanted ability, for example, crawling or showing empathy, thus denying ability identity security (being at ease with one's ability). As to mobility we demonize crawling to sell wheelchair-based mobility, we demonize wheelchairs to sell bionics and exoskeletons-based mobility and we increasingly will demonize species-typical mobilities to sell cyborgbased mobilities (faster than 'normal' walking) and other mobility enhancements, expecting new mobility and other abilities from humans.

I suggest there is a need for an improvement in the process of ability expectation and ableism governance, which concerns itself with ascertaining and anticipating societal impacts of ability expectations and ableism (Wolbring, 2010, 2019) and minimizing negative impacts. Ability expectation and ableism governance can make use of the concepts of cherry-picking and the demonization of abilities, as part of its system analysis and (a) efforts to connect parallel debates aroundability-based discussions, (b) its efforts to map out and make visible ability expectations and ableism conflicts between groups and individuals, and (c) to develop conflict resolution mechanisms for these conflicts. That how we govern the use of ability expectations and ableism needs to improve is evident in the unresolved ability expectation and ableism conflicts between groups and individuals and a lack of ability expectation and ableism peace (Goodley \& Lawthom, 2019; Wolbring, 2017; Wolbring et al., 2020). Drastic changes to come in ability expectations and ability norms triggered by ongoing discussions around environmental issues, artificial intelligence and machine learning and shifts in abilities triggered by Covid-19 realities will add to the problem by generating new ability expectations and ableism conflicts between groups and individuals.

Tools exist to help with the governance endeavour such as ability expectation exercises, which can make visible ability privileges, ability inequities and the lack of ability security and ability identity security (Wolbring, 2019; Wolbring et al., 2020), as well as the BIAS FREE FRAMEWORK, a tool to make visible social hierarchies (Eichler \& Burke, 2006) including social hierarchies based on abilities one has. Many more tools are needed, especially tools that enable ability expectations and ableism conflict resolutions. I leave you with this quote from a dialogue of the two main characters in a computer game that highlights that ability is a currency and that how we govern ability expectations will define us.

\section{Conversation between Alex D and Paul Denton}

- Paul Denton: If you want to even out the social order, you have to change the nature of power itself. Right? And what creates power? Wealth, physical strength, legislation - maybe - but none of those is the root principle of power.

- Alex D: I'm listening. 
- Paul Denton: Ability is the ideal that drives the modern state. It's a synonym for one's worth, one's social reach, one's "election," in the Biblical sense, and it's the ideal that needs to be changed if people are to begin living as equals.

- Alex D: And you think you can equalize humanity with biomodification?

- Paul Denton: The commodification of ability - tuition, of course, but, increasingly, genetic treatments, cybernetic protocols, now biomods - has had the side effect of creating a selfperpetuating aristocracy in all advanced societies. When ability becomes a public resource, what will distinguish people will be what they do with it. Intention. Dedication. Integrity. The qualities we would choose as the bedrock of the social order. (Wikiquote, 2019)

\section{References}

Abraham, A. (2017, 14 August). The highs and lows of clubbing with a physical disability. VICE. https://www.vice.com/en_ca/article/a33gjg/the-highs-and-lows-of-clubbing-with-a-physical-disability

Abrams, T., \& Abbott, D. (2021). Disability, deadly discourse, and collectivity amid coronavirus (COVID-19). Scandinavian Journal of Disability Research, 22(1), 168-174. http://doi.org/10.16993/sjdr.732.

Alkire, S., \& Black, R. (1997). A practical reasoning theory of development ethics: furthering the capabilities approach. Journal of International Development, 9(2), 263-279. https://doi.org/10.1002/(SICI)10991328(199703)9:2<263::AID-JID439>3.0.CO;2-D

Avenue Calgary. (2018, July 26). 10 Most pedestrian-friendly and walkable communities in Calgary. Avenue Calgary. https://www.avenuecalgary.com/Best-Neighbourhoods/2018/Calgarys-Most-WalkableNeighbourhoods/

Baafi, S. (2014). Ghana: Returning to school with sanitation access - Abudu, age 31*. World Vision. https://www.wvi.org/sites/default/files/WVI_Hopes_and_Dreams_final.docx

Balderston, S. (2013). Victimized again? Intersectionality and injustice in disabled women's lives after hate crime and rape. In M. T. Segal \& V. Demos (Eds.), Gendered perspectives on conflict and violence: Part A (Advances in Gender Research) (Vol. 18, pp. 17-51). Emerald Group Publishing Limited. https://doi.org/10.1108/S1529-2126(2013)000018A005

Britannica, T. Editors of Encyclopaedia (2013). Ableism. Encyclopaedia Britannica. https://www.britannica.com/topic/ableism

Campbell, F. K. (2008). Exploring internalized ableism using critical race theory. Disability \& Society, 23(2), 151-162. https://doi.org/10.1080/09687590701841190

Chesney-Lind, M., \& Eliason, M. (2006). From invisible to incorrigible: The demonization of marginalized women and girls. Crime, Media, Culture, 2(1), 29-47. https://doi.org/10.1177/1741659006061709

Cerebral Palsy Research Network. (2015, 24 July). The little girl who crawled up the Capitol steps 25 years later: Jennifer Keelan and the ADA. Cerebral Palsy Research Network. http://cpdailyliving.com/thelittle-girl-who-crawled-up-the-capitol-steps-25-years-later-jennifer-keelan-and-the-ada/ 
Duncan, D. T., Aldstadt, J., Whalen, J., Melly, S. J., \& Gortmaker, S. L. (2011). Validation of Walk Score ${ }^{\circledR}$ for estimating neighborhood walkability: An analysis of four US metropolitan areas. International Journal of Environmental Research and Public Health, 8(11), 4160-4179.

https://doi.org/10.3390/ijerph8114160

Eco-ability facebook group members. (2016). Eco-ability: Animal, earth and disability liberation. Facebook. https://www.facebook.com/groups/ecoability/

Edwards, C. (2021). Geographies of security and disabled people's urban lives. International Journal of Urban and Regional Research. https://www.ijurr.org/spotlight-on/disabling-city/geographies-ofsecurity-and-disabled-peoples-urban-lives/

Eichler, M., \& Burke, M. A. (2006). Building an integrative analytical system for recognizing and eliminating inEquities. (BIAS FREE framework). ETH Zürich, Center for Security Studies. https://ethz.ch/content/specialinterest/gess/cis/center-for-securities-studies/en/services/digitallibrary/publications/publication.html/128225

Eromosele, F. (2020). Frantz Fanon in the Time of Mad Studies. World Futures, 76(3), 167-187. https://doi.org/10.1080/02604027.2020.1730737

Eskytè, I., Lawson, A., Orchard, M., \& Andrews, E. (2020). Out on the streets - Crisis, opportunity and disabled people in the era of Covid-19: Reflections from the UK. Alter, 14(4), 329-336. https://doi.org/10.1016/j.alter.2020.07.004

Farmer, G. T., \& Cook, J. (2013). Understanding climate change denial. In G. T. Farmer \& J. Cook, Climate change science: A modern synthesis (pp. 445-466). Springer Netherlands. https://doi.org/10.1007/978-94-007-5757-8_23

Fenney, D. (2017). Ableism and disablism in the UK environmental movement. Environmental Values, 26(4), 503-522. https://doi.org/10.3197/096327117X14976900137377

Fenney Salkeld, D. (2019). Environmental citizenship and disability equality: The need for an inclusive approach. Environmental Politics, 28(7), 1259-1280.

https://doi.org/10.1080/09644016.2017.1413726

Fox, E. J., \& Hoch, S. J. (2005). Cherry-picking. Journal of Marketing, 69(1), 46-62. https://doi.org/10.1509/jmkg.69.1.46.55506

Frank, L. D., Sallis, J. F., Saelens, B. E., Leary, L., Cain, K., Conway, T. L., \& Hess, P. M. (2010). The development of a walkability index: Application to the Neighborhood Quality of Life Study. British Journal of Sports Medicine, 44(13), 924-933. https://doi.org/10.1136/bjsm.2009.058701

Frederick, A., \& Shifrer, D. (2019). Race and disability: From analogy to intersectionality. Sociology of Race and Ethnicity, 5(2), 200-214. https://doi.org/10.1177/2332649218783480

Goodley, D., \& Lawthom, R. (2019). Critical disability studies, Brexit and Trump: A time of neoliberalableism. Rethinking History, 23(2), 233-251. https://doi.org/10.1080/13642529.2019.1607476

Goodley, D., Lawthom, R., \& Cole, K. R. (2014). Posthuman disability studies. Subjectivity, 7(4), 342-361. https://doi.org/10.1057/sub.2014.15

Hamilton, J. M., \& Neimanis, A. (2018). Composting feminisms and environmental humanities. Environmental Humanities, 10(2), 501-527. https://doi.org/10.1215/22011919-7156859 
Hamraie, A. (2021). Crip mobility justice: Ableism and active transportation debates. International Journal of Urban and Regional Research. https://www.ijurr.org/spotlight-on/disabling-city/crip-mobilityjustice/

Human Development and Capability Association. (2021). Human Development and Capability Association. http://www.hd-ca.org/index.php

Jaffe, R. (2021). Introduction: The disabling city. International Journal of Urban and Regional Research. https://www.ijurr.org/spotlight-on/disabling-city/introduction-the-disabling-city/

Jenks, A. B., \& Obringer, K. M. (2020). The poverty of plastics bans: Environmentalism's win is a loss for disabled people. Critical Social Policy, 40(1), 151-161. https://doi.org/10.1177/0261018319868362

Jones, O. (2020). Chavs: The demonization of the working class. Verso.

Kattari, S. K. (2015). Examining ableism in higher education through social dominance theory and social learning theory. Innovative Higher Education, 40(5), 375-386. https://doi.org/10.1007/s10755-0159320-0

Landorf, H., Doscher, S., \& Rocco, T. (2008). Education for sustainable human development: Towards a definition. Theory and Research in Education, 6(2), 221-236.

https://doi.org/10.1177/1477878508091114

Leblanc, S., \& Kinsella, E. A. (2016). Toward epistemic justice: A critically reflexive examination of 'sanism' and implications for knowledge generation. Studies in Social Justice, 10(1), 59-78.

https://doi.org/10.26522/ssj.v10i1.1324

Liasidou, A. (2013). Intersectional understandings of disability and implications for a social justice reform agenda in education policy and practice. Disability \& Society, 28(3), 299-312. https://doi.org/10.1080/09687599.2012.710012

Lillywhite, A., \& Wolbring, G. (2020). Coverage of artificial intelligence and machine learning within academic literature, Canadian newspapers, and twitter tweets: The case of disabled people. Societies, 10(1), 23 1-27. https://doi.org/10.3390/soc10010023

Litman, T. (2007). Economic value of walkability. Tcstreetforpeople. http://tcstreetsforpeople.org/sites/tcstreetsforpeople.org/files/LitmanEconomicValueOfWalkability.pdf

Lwanga-Ntale, C. (2003, April 7-9). Chronic poverty and disability in Uganda [Conference Presentation]. International Conference: Staying Poor: Chronic Poverty and Development Policy, University of Manchester. http://www.chronicpoverty.org/pdfs/2003conferencepapers/lwangaNtale.pdf

Miller, P., Parker, S., \& Gillinson, S. (2004). Disablism. How to tackle the last prejudice. Demos. http://www.demos.co.uk/files/disablism.pdf

Mizrahi, M. (2015). Historical inductions: New cherries, same old cherry-picking. International Studies in the Philosophy of Science, 29(2), 129-148. https://doi.org/10.1080/02698595.2015.1119413

Morrow, M. (2017). "Women and madness" revisited: The promise of intersectional and mad studies frameworks. In M. Morrow, \& L. Malcoe (Eds.), Critical inquiries for social justice in mental health (pp. 33-59). University of Toronto Press.

Murphy, K. R., \& Aguinis, H. (2019). HARKing: How badly can cherry-picking and question trolling produce bias in published results? Journal of Business and Psychology, 34(1), 1-17.

https://doi.org/10.1007/s10869-017-9524-7 
Nocella, A. J., Bentley, J., \& Duncan, J.M. (Eds.) (2012). Earth, animal and disability liberation: The rise of the eco-ability movement. Peter Lang.

Nocella, A. J., George, A. E., \& Schatz, J. L. (Eds.) (2017). The intersectionality of critical animal, disability, and environmental studies: Toward eco-ability, justice, and liberation. Lexington Books.

Nussbaum, M. (2011). Creating capabilities: The human development approach. Belknap Press of Harvard University Press.

Roberts-Cady, S. (2017). Exploring Eco-ability: Reason and normalcy in ableism, speciesism and ecocide. In A. J. Nocella, A. E. George, \& J. L. Schatz (Eds.), The intersectionality of critical animal, disability, and environmental studies: Toward eco-ability, justice, and liberation (pp. 99-114). Lexington Books.

Robeyns, I. (2003). Sen's capability approach and gender inequality: Selecting relevant capabilities. Feminist Economics, 9(2-3), 61-92. https://doi.org/10.1080/1354570022000078024

Runswick-Cole, K., \& Goodley, D. (2015). Disability, austerity and cruel optimism in big society: Resistance and "the disability commons". Canadian Journal of Disability Studies, 4(2), 162-186.

https://doi.org/10.15353/cjds.v4i2.213

Ryan, F. (2020). Crippled: Austerity and the demonization of disabled people. Verso.

Seskus, T. (2011). How we measured walkability in Calgary using Walk Score. Calgary Herald. http://www.calgaryherald.com/measured+walkability+Calgary+using+Walk+Score/5519865/story.ht $\mathrm{ml}$

Sleeter, C. E. (1986). Learning disabilities: The social construction of a special education category. Exceptional Children, 53(1), 46-54. https://doi.org/10.1177/001440298605300105

Sleeter, C. E. (1987). Why is there learning disabilities? A critical analysis of the birth of the field in its social context. In T. S. Popkewitz (Ed.), The foundations of the school subjects (pp. 210-237). Palmer Press.

Sripokangkul, S., Crumpton, C. D., \& Draper, J. (2020). Demonization and violence as tools of institutional power: The social cage of Thailand. Social identities, 26(4), 446-460. https://doi.org/10.1080/13504630.2020.1767056

The Asahi Shimbun. (2017). Airline rules force disabled man to crawl up ramp to plane. The Asahi Shimbun. http://www.asahi.com/ajw/articles/AJ201706280043.html

Underwood, B. D. (2007). Facts on the ground and federalism in the air: The Solicitor General's effort to defend federal statutes during the federalism revival. Journal of Civil Rights and Economic Development, 21(2), Article 3. https://scholarship.law.stjohns.edu/jcred/vol21/iss2/3/

Vehmas, S. \& Taylor, S.J. (2004). Ethical analysis of the concept of disability. Mental Retardation, 42(3), 209222. https://doi.org/10.1352/0047-6765(2004)42<209:EAOTCO>2.0.CO;2

Viney, S. (2016, June 11). Bolivia disability protests: Demonstrators hold sit-ins, clash with security forces amid demands for benefits. ABC News. http://www.abc.net.au/news/2016-06-12/bolivia-disabilityprotests-met-with-violence-amid-demands/7501914

Visitability. (2018). Visitability. National Council on Independent Living, USA. https://visitability.org/aboutvisitability/statistics-and-demographics/

Vydra, S., \& Klievink, B. (2019). Techno-optimism and policy-pessimism in the public sector big data debate. Government Information Quarterly, 36(4), 101383. https://doi.org/10.1016/j.giq.2019.05.010 
Walk Score. (2018). Walk Score Methodology. Walk Score. https://www.walkscore.com/methodology.shtml

Walker, R. (2000). Learning if policy will work: The case of New Deal for Disabled People. Policy Studies, 21(4), 313-332. https://doi.org/10.1080/713691374

Whitesel, J. (2017). Intersections of multiple oppressions: Racism, sizeism, ableism, and the "illimitable etceteras" in encounters with law enforcement. Sociological Forum, 32(2), 426-433. https://doi.org/10.1111/socf.12337

Wikiquote. (2019, July 24). Deus Ex: Invisible War. http://en.wikiquote.org/wiki/Deus_Ex:_Invisible_War

Winstanley, C. (2012). Alluring ideas: Cherry picking policy from around the world. Journal of Philosophy of Education, 46(4), 516-531. https://doi.org/10.1111/j.1467-9752.2012.00876.x

Wolbring, G. (2008a). The politics of ableism. Development, 51(2), 252-258. https://doi.org/10.1057/dev.2008.17

Wolbring, G. (2008b). Why NBIC? Why human performance enhancement? Innovation: The European Journal of Social Science Research, 21(1), 25-40. https://doi.org/10.1080/13511610802002189

Wolbring, G. (2010). Ableism and favoritism for abilities governance, ethics and studies: New tools for nanoscale and nanoscale enabled science and technology governance. In S. Cozzens \& J. M.Wetmore (Eds.), The Yearbook of Nanotechnology in Society, vol. II: The Challenges of Equity and Equality (pp. 89-104). Springer.

Wolbring, G. (2012). Ethical theories and discourses through an ability expectations and ableism lens: The case of enhancement and global regulation. Asian Bioethics Review, 4(4), 293-309.

Wolbring, G. (2014). Ability privilege: A needed addition to privilege studies. Journal for Critical Animal Studies, 12(2), 118-141.

Wolbring, G. (2016). Employment, disabled people and robots: What is the narrative in the academic literature and Canadian newspapers? Societies, 6(2), Article 15. https://doi.org/10.3390/soc6020015

Wolbring, G. (2017, August 11). Why 'ability expectations' must be central to debates on science and our future. The Conversation, Canada. https://theconversation.com/why-ability-expectations-must-becentral-to-debates-on-science-and-our-future-82055

Wolbring, G. (2019). Ability expectation and ableism governance: An essential aspect of a culture of peace. In D. R. J. Macer (Ed.), Legacies of love, peace and hope: How education can overcome hatred and divide (pp. 116-126). Eubious Ethics Institute.

Wolbring, G. (2020a). Ability expectation and ableism glossary. Gregor Wolbring and the WolbPack. https://wolbring.wordpress.com/ability-expectationableism-glossary/

Wolbring, G. (2020b). Violence and abuse through an ability studies lens. Indian Journal of Critical Disability Studies 1(1), 41-67. https://jcdsi.org/index.php/injcds/article/view/46

Wolbring, G., \& Burke, B. (2013). Reflecting on Education for Sustainable Development through Two Lenses: Ability Studies and Disability Studies. Sustainability, 5(6), 2327-2342. https://doi.org/10.3390/su5062327

Wolbring, G., Deloria, R., Lillywhite, A., \& Villamil, V. (2020). Ability expectation and ableism peace. Peace Review, 31(4), 449-458. https://doi.org/10.1080/10402659.2019.1800929 
Wolbring, G., \& Ghai, A. (2015). Interrogating the impact of scientific and technological development on disabled children in India and beyond. Disability and the Global South, 2(2), 667-685.

Wolbring, G., \& Yumakulov, S. (2015). Education through an ability studies lens. Zeitschrift für Inklusion, (2). https://www.inklusion-online.net/index.php/inklusion-online/article/view/278

Wong, A. (2019). The rise and fall of the plastic straw. Sucking in crip defiance. Catalyst: Feminism, Theory, Technoscience, 5(1), 1-12. https://doi.org/10.28968/cftt.v5i1.30435

\section{Author}

Gregor Wolbring is a Professor at the University of Calgary (Canada), Cumming School of Medicine, Community Health Sciences, Community Rehabilitation and Disability Studies. He has three main areas of research: ability studies, disability studies and impact and governance of new and emerging sciences and technologies.

E-Mail: gwolbrin@ucalgary.ca; Homepage: https://wolbring.wordpress.com/ 